\title{
PENGEMBANGAN MEDIA BERBASIS TEKNOLOGI AUGMENTED REALITY BERMUATAN WAWASAN KEBANGSAAN PADA TOKOH KEPAHLAWANAN
}

\author{
Eliya Rochmah ${ }^{1}$, Erna Labudasari ${ }^{2}$, Nurani Amalia ${ }^{3}$ \\ Universitas Muhammadiyah Cirebon
}

\begin{abstract}
This study is to know how a media plan of augmented reality-based which contains nationality knowledge in studying the national heroes. The method of this study was research and developement $(R \& D$ with was applied four instruments, they are questionnaires for experts in media, lesson, then teachers and students' responses in term of applying the media. While the subject of this study which became its trial was thirty 5th students of SDN Kangrgraksan, Kota Cirebon. The result shows that the media plan was developed thorugh some steps, they are potential and problem, collecting data, designing product, validating design, revising design, and testing the product. The validation result of the media was obtained $94.4 \%$ which is categorized very appropriate and the validation lesson of expert was gained that the lesson is categorized valid. Besides that, the students' responses toward it ware $83.3 \%$ said very agree and others $16.7 \%$ agree and teachers' responses toward it were $73.3 \%$ and it was categorized good.
\end{abstract}

Keyword: Augmented Reality, Nationality Knowledge, National Heroes

\begin{abstract}
Abstrak: Tujuan penelitian ini untuk mengetahui bagaimana perancangan media berbasis teknologi augmented reality bermuatan wawasan kebangsaan pada materi tokoh kepahlawanan. Metode penelitian yang digunakan adalah Research and Development $(R \& D)$ dengan menggunakan empat instrumen yaitu angket ahli media, angket ahli materi, angket respon siswa dan guru tentang media. Sementara subjek penelitian yang dijadikan uji coba pemakaian adalah siswa kelas V Sekolah Dasar Negeri Kanggraksan, Kecamatan Harjamukti, Kota Cirebon sebanyak 30 siswa. Hasil penelitian menunjukkan bahwa perancangan media berbasis teknologi augmented reality bermuatan wawasan kebangsaan dikembangkan melalui tahapan potensi dan masalah, pengumpulan data, desain produk, validasi desain, revisi desain, dan uji coba pemakaian. Hasil validasi media diperoleh $94.4 \%$ media dalam kategori Sangat Layak dan hasil validasi ahli materi diperoleh hasil bahwa materi tergolong valid. Selain itu, hasil respon siswa terhadap media adalah sebanyak $83.3 \%$ siswa menjawab Sangat Setuju dan sisanya $16.7 \%$ menjawab Setuju dan hasil respon guru terhadap media adalah $73.3 \%$ dalam kategori Baik.
\end{abstract}

Kata Kunci: Augmented Reality, Wawasan Kebangsaan, Tokoh Pahlawan

\section{PENDAHULUAN}

Indonesia merupakan negara yang memiliki beragam suku, bangsa, etnis dan agama. Banyak perpecahan yang terjadi dikarenakan adanya perbedaan ini. Adanya semboyan Bhinneka Tunggal Ika sepatutnya dijadikan sebagai landasan bahwa walaupun berbeda-beda maka tetap satu. Semboyan negara tersebut hendaknya dijadikan sebagai landasan agar tidak lagi terjadi perpecahan antar perbedaan suku, bangsa, etnis dan agama.

Dampak perpecahan yang paling riskan ditemui adalah generasi muda. Generasi muda yang seharusnya menjadi penerus bangsa mudah terprovokasi oleh suatu kelompok yang menyebabkan mereka terpecah belah. Banyak kasus yang terjadi yang melibatkan generasi muda khususnya siswa sekolah dasar. Contohnya adalah

\footnotetext{
'Universitas Muhammadiyah Cirebon, Email: eliya.rochmah国umc.ac.id

${ }^{2}$ Universitas Muhammadiyah Cirebon, Email: erna.labudasari|⿴囗玉

${ }^{3}$ Universitas Muhammadiyah Cirebon, Email: nurani.amalia国umc.ac.id
} 
kasus bullying antar teman sekelas, kasus tawuran antar pelajar dan konsumsi minuman keras dan obat-obatan terlarang.

Generasi muda Indonesia saat ini juga sedang dimanjakan oleh berbagai tayangan dari luar negeri seperti "The Avengers". Generasi muda lebih menyukai budaya luar dibandingkan dengan budaya sendiri. Ketika ditanya tentang kebudayan sendiri, mereka akan berkata "kuno" dan ketinggalan jaman. Dan ketika ditanya mengenai pahlawan Indonesia mereka tidak mengetahui apalagi menghapal sejarah dan perannya pada masa penjajahan dulu. Mereka lebih menghapal tokoh-tokoh dalam film The Avengers dibandingkan dengan tokoh pahlawan nasional Indonesia. Hal tersebut menunjukkan bahwa kepekaan generasi muda terhadap budaya bangsa sendiri semakin melemah dan kecintaan terhadap tanah air dan semangat kebangsaan generasi muda semakin pudar.

$$
\text { Kecintaan dan semangat }
$$

kebangsaan tersebut adalah bagian dari pendidikan karakter. Di jaman sekarang, isu pendidikan karakter menjadi hal yang penting untuk dibahas. Pendidikan karakter menjadi sesuatu hal yang penting dan harus melekat di setiap generasi muda saat ini. Sekolah dasar seharusnya dapat menjadi salah satu fasilitator dalam memberikan pemahaman mengenai pendidikan karakter dan wawasan kebangsaan agar generasi muda lebih peka terhadap lingkungan dan lebih cinta terhadap pahlawan dan tanah airnya (Rochmah \& Labudasari, 2018).

Dengan semangat kebangsaan yang kuat, cerminan karakter Indonesia akan muncul dalam segala aktivitas yang ditujukan bagi peningkatan kualitas bangsa. Hal ini sejalan dengan Bung Karno yang pernah mengatakan bahwa "hanya bangsa yang besar adalah bangsa yang menghormati jasa-jasa para pahlawan". Dengan kutipan tersebut menjelaskan bahwa jika bangsa Indonesia ingin maju dan berkembang menjadi bangsa yanng besar, maka bangsa tersebut haruslah menghormati perjuangan yang telah dilakukan oleh para pahlawan. Oleh karena itu, generasi muda hendaknya diajarkan untuk mengenang jasa-jasa serta sikap kepahlawanan para pejuang.

$$
\text { Pendidikan karakter juga }
$$

seharusnya diintegrasikan dengan pembelajaran di sekolah khususnya sekolah dasar. Salah satu pelajaran yang dapat menanamkan karakter dan meningkatkan wawasan kebangsaan adalah pelajaran Ilmu Pengetahuan Sosial (IPS). IPS mengajarkan siswa tentang sejarah Indonesia, pengetahuan demokratis, bernegara yang berlandaskan kearifan lokal, semangat nasiona, dan wawasan global serta semangat kebangsaan dapat tumbuh untuk memperkuat karakter Indoneisa. Materi dalam pelajaran IPS yang dapat meningkatkan wawasan kebangsaan siswa salah satunya adalah materi tokoh kepahlawanan.

Materi tokoh kepahlawanan biasanya disajikan dalam bentuk buku teks dan Lembar Kerja Siswa (LKS). Gambar tokoh pahlawan hanya disajikan dalam bentuk gambar hitam dan putih tanpa memberikan kesan menarik terhadap siswa. Dengan media seperti ini, tentunya dirasa kurang efektif dan cenderung membuat siswa merasa cepat bosan.

Salah satu solusi untuk menanamkan wawasan kebangsaan yaitu dengan mengintegrasikan pelajaran tokoh pahlawan dengan media teknologi. Teknologi yang sedang berkembang saat ini yang dapat diterapkan adalah Augmented Reality. Dengan media ini, materi tokoh kepahlawanan akan disajikan secara lebih menarik dan interaktif sehingga diharapkan akan menciptakan pembelajaran yang efektif dan dapat meningkatkan hasil belajar serta pendidikan karakter siswa khususnya wawasan kebangsaan siswa.

Penelitian mengenai media pembelajaran berbasis teknologi augmented reality pernah berhasil dilakukan oleh Nur Jazilah (2016). Hasil penelitian adalah rata-rata siswa merasa senang dan termotivasi menggunakan media augmented reality pada 
pembelajaran wudhu di sekolah. Penelitian juga dilakukan oleh Safaat, Nazruddin (2014), hasil penelitian menunjukkan bahwa dari hasil kuesioner yang diberikan kepada siswa dan guru diperoleh nilai 84.85\% menyatakan bahwa Aplikasi ARBook Tata Surya sangat membantu dalam memahami tata surya dan memberikan suatu kajian yang lebih menarik serta dapat mengatasi kekurangan alat peraga. Penelitian lain juga dilakukan oleh Takhta Akrama Ananda dkk (2015) diperoleh hasil bahwa aplikasi yang dikembangkan mampu menampilkan semua visualisasi objek 3D dan mampu menarik minat siswa dalam mempelajari planet-planet di tata surya.

Dari beberapa penelitian yang telah dilakukan mengenai augmented reality diduga bahwa dengan mengembangkan media berbasis teknologi augmented reality bermuatan wawasan kebangsaan dapat menghasilkan media yang layak digunakan dan memberikan respon yang baik dari guru dan siswa yang menjadi objek uji coba.

\section{TINJUAN PUSTAKA}

\section{Wawasan Kebangsaan}

Wawasan kebangsaan merupakan suatu sikap kecintaan terhadap tanah air. Menurut Hadi (2009) wawasan kebangsaan adalah kesadaran berbangsa, yakni rasa yang lahir secara alamiah karena adanya kebersamaan sosial yang tumbuh dari kebudayaan, sejarah, dan aspirasi perjuangan masa lampau, serta kebersamaan dalam menghadapi tantangan sejarah masa kini. Nasionalisme dan wawasan kebangsaan mengikat warga negara dalam beberapa hal, yakni (a) memiliki kesadaran sebagai satu bangsa, yang dapat memperkuat rasa kebangsaan, persatuan dan kesatuan, (b) jiwa, semangat, dan nilai-nilai patriotik, yaang berkaitan dengan perasaan cinta tanah air, cinta kepada tanah tumpah darah, cinta kepada negara dan bangsa, cinta kepada milik budaya bangsa sendiri, kerelaan untuk membela tanah airnya, (c) jiwa, semangat dan nilai-nilai kreatif dan inovatif, dan (d) jiwa, semangat, dan nilai-nilai yang mampu membentuk kepribadian, watak dan budi luhur bangsa (Efendi, 2008).

Nilai Wawasan Kebangsaan yang terwujud dalam persatuan dan kesatuan bangsa memiliki enam dimensi yang bersifat mendasar dan fundamental, yaitu:

1. Penghargaan terhadap harkat dan martabat manusia sebagai makhluk ciptaan Tuhan Yang Maha Esa;

2. Tekad bersama untuk berkehidupan kebangsaan yang bebas, merkeka, dan besatu;

3. Cinta akan tanah air dan bangsa;

4. Demokrasi atau kedaulatan rakyat;

5. Kesetiakawanan sosial;

6. Masyarakat adil-makmur.

Wawasan kebangsaan juga identik dengan nilai patriotisme. Patriotisme merupakan kecintaan terahadap tanah air, bangsa dan negara (Rahayuningsih, 2009). Berdasarkan pendapat tersebut, wawasan kebangsaan juga bisa dilihat dari jiwa patriotisme siswa yang menunjukkan sikap cinta tanah air dan bangsa.

Berdasarkan uraian tersebut, dapat dirangkum bahwa wawasan kebangsaaan adalah sudut pandang suatu bangsa dalam memahami keberadaan jati diri dan lingkungannya pada dasarnya merupakan penjabaran dari falsafah bangsa itu sesuai dengan keadaan wilayah suatu negara dan sejarah yang dialaminya. Wawasan yang dikembangkan dalam media berbasis teknologi augmented reality adalah nilainilai patriotic yang berkaitan dengan perasaan cinta tanah air, cinta kepada tanah tumpah darah, cinta kepada negara dan bangsa, cinta kepada milik budaya bangsa sendiri, kerelaan untuk membela tanah airnya, jiwa semangat, kesadaran sebagai satu bangsa, yang dapat memperkuat rasa kebangsaan, persatuan dan kesatuan.

\section{Teknologi Augmented Reality}

Teknologi augmented reality adalah suatu teknologi yang memadukan antara dunia nyata dengan dunia virtual. Pengguna akan diajak untuk memasuki suatu dunia virtual yang seolah-olah menjadi nyata. Menurut Hadi dan Sulistyo dalam Yasin, 
dkk. (2016) Augmented reality adalah teknologi yang dapat menggabungkan benda maya berjenis 2 dimensi atau 3 dimensi yang akan ditambahkan ke dalam lingkungan nyata dan menggabungkan keduanya sehingga menciptakan ruang gabungan yang tercampur dan memproyeksikannya ke dalam waktu nyata atau real time.

Cara kerja augmented reality yang cukup sederhana dengan berdasarkan deteksi citra dan biasa disebut dengan marker. Sebagai contoh, sebuah kamera telah dikalibrasi dapat mendeteksi marker yang telah didesain, lalu setelah mendeteksi marker tersebut, kamera akan melakukan pencocokan dengan database yang telah dibuat sebelumnya. Dan jika hasilnya cocok, maka informasi dari marker akan digunakan menampilkan objek 2D/3D yang telah didesain di depan layar penggunanya, tetapi jika marker tidak cocok dengan database maka informasi dari marker tidak akan dapat diolah. (Ammatia, 2012).

Augmented reality sudah banyak dimanfaatkan salah satunya dibidang pendidikan. Beberapa penelitian yang memanfaatkan teknologi Augmented reality adalah tentang pembuatan aplikasi pembelajaran wudhu untuk anak. Hasil dari penelitian ini adalah berupa aplikasi pembelajaran wudhu berbasis augmented reality dengan menampilkan objek 3D gerakan wudhu pada buku panduan wudhu (Jazilah, 2016). Penelitian lain yaitu mengenai pemanfaatan augmented reality untuk pembelajaran tentang hewan pada anak-anak. Hasil dari aplikasi berupa objek 3D hewan yang dibuat dengan menggunakan software Cinema 3D serta unity 3D (Martinez, Mario Z, et al, 2013).

Pada pengembangan Media Berbasis Teknologi Augmented reality Bermuatan Wawasan Kebangsaan pada Materi Tokoh Kepahlawanan akan menghasilkan sebuah aplikasi yang memiliki fitur dengan menampilkan wajah pahlawan berupa gambar 2D/3D di wajah siswa sebagai pengguna, seolah-olah wajah siswa akan berubah menjadi wajah tokoh pahlawan. Siswa juga bisa melihat deskripsi tokoh pahlawan berupa deskripsi tentang riwayat hidup dan kisah singkat perjuangan tokoh pahlawan pada saat memperjuangkan kemerdekaan sehingga akan tertanam wawasan kebangsaan siswa dan tercipta pembelajaran yang lebih interaktif, menarik dan menyenangkan. Spesifikasi detail produk yang dihasilkan adalah sebagai berikut.

1. Produk berupa media berbasis augmented reality bermuatan wawasan kebangsaan pada materi tokoh kepahlawanan.

2. Media yang dikembangkan menyajikan deskripsi tentang riwayat hidup dan kisah singkat perjuangan tokoh pahlawan pada saat memperjuangkan kemerdekaan.

3. Media yang dikembangkan memuat konten audio visual yang baik dan mudah dipahami oleh siswa.

4. Media yang dikembangkan menggunakan bahasa Indonesia.

5. Media yang dikembangkan berbasis desktop.

Secara detail langkah pembelajaran menggunakan media berbasis teknologi augmented reality adalah sebagai berikut.

1. Siswa mengarahkan wajah ke webcam laptop yang telah terpasang media augmented reality.

2. Siswa bisa mensimulasikan dan menampilkan tokoh pahlawan di wajahnya.

3. Siswa dapat mengetahui deskripsi tentang riwayat hidup dan kisah singkat perjuangan tokoh pahlawan pada saat memperjuangkan kemerdekaan.

4. Siswa dapat melihat video ilustrasi tentang tokoh pahlawan kemerdekaan.

\section{Pembelajaran IPS di Sekolah Dasar}

Pelajaran IPS di SD memiliki peranan penting dalam pembentukan wawasan khususnya tentang kepahlawanan yang ada di Indonesia. Tujuan utama pengajaran Social Studies (IPS) adalah untuk memperkaya dan mengembangkan 
kehidupan anak didik dengan mengembangkan kemampuan dalam lingkungannya dan melatih anak didik untuk menempatkan dirinya dalam masyarakat yang demoktratis, serta menjadikan negaranya sebagai tempat hidup yang lebih baik.

Tujuan mempelajari ilmu pengetahuan di Indonesia untuk memberikan pengetahuan yang merupakan kemampuan untuk mengingat kembali atau mengenal kembali atau mengenal ide-ide atau penemuan yang telah dialami dalam bentuk yang sama atau dialami sebelumnya. Melalui pembelajaran ips yang integratif dengan didasari pemahaman historis-filosofis tentang Indonesia yang berlandaskan kearifan lokal, semangat nasional, dan wawasan global, semangat kebangsaan dapat tumbuh untuk memperkuat karakter Indonesia.

Semangat kebangsaan dapat tertanam melalui materi kepahlawanan di kelas $\mathrm{V}$ semester 2 sebagaimana telah dicantumkan dalam Standar Kompetensi (SK) dan Kompetensi Dasar (KD) berikut ini.

SK : 2. Menghargai jasa dan peranan tokoh perjuangan dalam mempersiapkan kemerdekaan Indonesia

$\mathrm{KD}$ : 2.1. Mendeskripsikan perjuangan para tokoh pejuang pada pada penjajah Belanda dan Jepang

\section{METODOLOGI PENELITIAN}

Metode penelitian yang digunakan adalah Research and Development $(R \& D)$. menurut Sugiyono (2010) menggunakan langkah-langkah dengan tahapan sesuai gambar berikut.

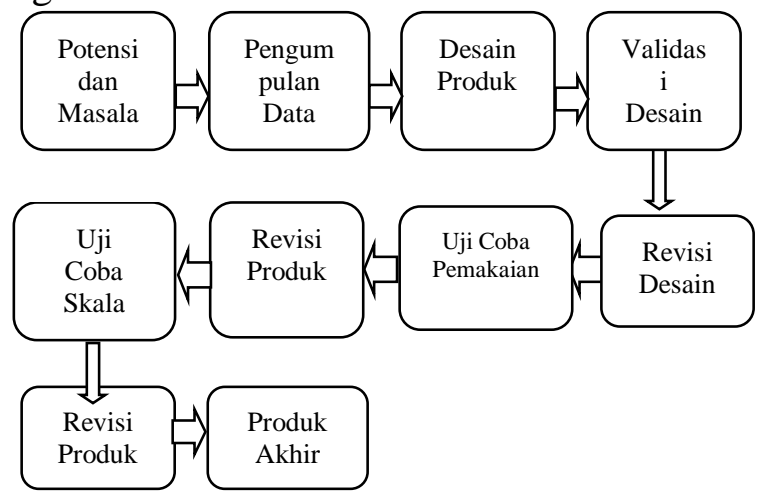

Gambar 1. Alur Pengembangan Produk

1. Identifikasi Potensi dan Masalah

Kegiatan pada tahapan ini adalah mengumpulkan berbagai informasi tentang tentang permasalahan, potensi yang dimiliki, pembelajaran yang telah dilaksanakan, analisis masalah serta identifikasi kebutuhan dalam pembelajaran yang akan digunakan sebagai acuan dalam mengembangkan produk media berbasis augmented reality.

2. Pengumpulan Data

Pada tahap ini yaitu dilakukan pengumpulan informasi tentang berbagai hal yang mendukung pengembangan media pembelajaran yaitu materi pelajaran IPS khususnya mengenai kepahlawanan yang bermuatan wawasan kebangsaan.

3. Desain Produk

Kegiatan yang dilakukan pada tahap ini adalah merancang desain media berbasis augmented reality bermuatan wawasan kebangsaan.

4. Validasi Desain

Desain media berbasis augmented reality yang telah dibuat selanjutnya produk divalidasi oleh 3 orang ahli yang terdiri dari 2 orang ahli media dan 1 orang ahli materi.

5. Revisi Produk

Revisi dilakukan berdasarkan penilaian, catatan, dan saran dari pakar yang telah memvalidasi.

6. Uji Coba Pemakaian

Uji coba pemakaian dilakukan untuk mengetahui respon guru dan siswa dalam penggunaan media, isi materi, penggunaan bahasa, dan desain dalam media berbasis augmented reality yang telah dikembangkan untuk memberikan masukan/perbaikan yang akan diujikan pada tahap uji coba pemakaian produk skala luas.

7. Revisi Produk

Setelah dilakukan uji coba produk, jika masih terdapat perbaikan kemudian disempurnakan kembali sehingga 
menjadi produk yang layak digunakan pada skala luas.

8. Uji Coba Skala Luas

Pada uji coba pemakaian media digunakan yaitu kelas VA dan VB yang masing-masing berjumlah 30 siswa. Uji coba digunakan untuk mengetahui bagaimana respon siswa dan guru tentang keterpakaian produk

9. Revisi Produk

Tahapan pelaksanaan pengembangan menurut Sugiyono (2010) disederhanakan sesuai dengan kebutuhan yang terdiri dari 3 tahap yaitu: (1) tahap pendahuluan (potensi, masalah dan pengumpulan data); (2) tahap perencanaan (desain produk); (3) tahap pengembangan (validasi desain, revisi desain, uji coba produk, revisi produk, uji coba pemakaian, revisi produk dan produk akhir).

Dalam penelitian ini, langkahlangkah yang dilakukan hanya pada uji coba pemakaian dan tidak sampai pada uji coba skala luas.

Instrumen yang digunakan adalah instrumen angket ahli media, instrumen angket ahli materi, angket respon siswa dan guru tentang media. Sementara subjek Subjek penelitian yang dijadikan uji coba pemakaian adalah siswa kelas V SDN Kanggraksan, Kota Cirebon sebanyak 30 siswa.

Teknik analisis data yang dilakukan adalah dengan menguji produk kepada 2 orang ahli media dan 1 orang ahli materi. Ahli media ditujukan kepada 2 dosen ahli teknologi dan ahli materi ditujukan kepada guru kelas V SDN Kanggraksan. Analisis data pengujian media dihitung dengan rumus:

$$
\text { Presentase kelayakan }(\%)=\frac{\text { skor yang diobservasi }}{\text { skoryang diharapkan }} \times 100 \%
$$

Setelah didapatkan presentase, kemudian data dikonversi ke dalam tabel interpretasi berikut.
Tabel 1. Interpretasi Presentase

\begin{tabular}{|c|c|c|}
\hline No. & Presentase & Interpretasi \\
\hline 1 & $0-20 \%$ & Sangat tidak layak \\
\hline 2 & $21-40 \%$ & Tidak layak \\
\hline 3 & $41-60 \%$ & Cukup \\
\hline 4 & $61-80 \%$ & Layak \\
\hline 5 & $81-100 \%$ & Sangat layak \\
\hline
\end{tabular}

Sumber: (Sudaryono, 2011)

\section{HASIL PENELITIAN \\ PEMBAHASAN \\ Hasil Penelitian \\ Identifikasi Potensi dan Masalah}

DAN

Pada tahap ini dilakukan pengumpulan berbagai informasi tentang permasalahan, potensi yang dimiliki, pembelajaran yang telah dilaksanakan, analisis masalah serta identifikasi kebutuhan dalam pembelajaran yang akan digunakan sebagai acuan dalam mengembangkan produk media berbasis augmented reality.Tahap yang dilakukan yaitu melakukan observasi awal di sekolah dan menggali informasi mengenai pembelajaran IPS yang sudah dilakukan. Dari hasil observasi yang dilakukan ditemukan bahwa: (1) tersedianya sarana penunjang pembelajaran seperti in focus; (2) pembelajaran IPS masih bersifat konvensional dengan media buku teks dan LKS; (3) siswa sangat antusias menggunakan media interaktif seperti audio visual. Permasalahan di sekolah diantaranya: (1) pembelajaran IPS kurang interaktif dan cenderung teacher center; (2) wawasan kebangsaan siswa rendah ditunjukkan dengan kurangnya pemahaman mengenai karakter tokoh-tokoh pahlawan; (3) sarana penunjang pembelajaran belum dimanfaatkan secara maksimal.

Setelah didapatkan analisis permasalahan di lapangan, tahap selanjutnya adalah melakukan analisis kebutuhan dimulai dari analisis spesifikasi produk media, software dan hardware yang dibutuhkan dalam pembuatan media.berikut ini adalah penjelasan masing-masing analisis kebutuhan dalam pembuatan media berbasis teknologi 
augmented reality bermuatan wawasan kebangsaan pada materi tokoh kepahlawanan di kelas V SDN Kanggraksan.

a. Analisis Kebutuhan Spesifikasi

Kebutuhan spesifikasi komputer yang dibutuhkan adalah komputer dengan sistem operasi windows XP yang dilengkapi dengan web camera.

b. Analisis kebutuhan software dan hardware

1. Analisis kebutuhan software

Kebutuhan software dalam pembuatan media berbasis teknologi augmented reality bermuatan wawasan kebangsaan pada materi tokoh kepahlawanan adalah unity 3D, metaio SDK, Adobe Photoshop CS3, Camtasia 8, dan Microsoft Power Point.

2. Analisis kebutuhan hardware

Komputer dengan spesifikasi minimal prosesor core i5, RAM 2 $\mathrm{GB}$, dan dilengkapi dengan web camera.

\section{Pengumpulan Data}

Pada tahap ini yaitu dilakukan pengumpulan informasi tentang berbagai hal yang mendukung pengembangan media pembelajaran yaitu materi pelajaran IPS khususnya mengenai kepahlawanan yang bermuatan wawasan kebangsaan. Kebutuhan data dalam pembuatan media berbasis teknologi augmented reality bermuatan wawasan kebangsaan pada materi tokoh kepahlawanan adalah datadata mengenai tokok-tokoh pahlawan Indonesia diantaranya adalah pahlawan pada masa kerajaan hindu, pahlawan pada masa kerajaan budha, pahlawan pada masa kerajaan islam, pahlawan yang memperjuangkan kemerdekaan, dan pahlawan yang mempertahankan kemerdekaan.

Data pahlawan tersebut diperoleh dari beberapa sumber diantaranya adalah buku teks pelajaran Ilmu Pengetahuan Sosial. Pengumpulan data yang diperlukan untuk media adalah berupa: gambar/foto pahlawan, biografi pahlawan, dan deskripsi pahlawan mengenai sejarah dan cerita singkat perjuangannya; (2) audio mengenai deskripsi pahlawan; (3) video mengenai cerita singkat dan deskripsi pahlawan. Selain itu data yang diperlukan untuk proses pembelajaran adalah: (1) penyusunan perangkat pembelajaran berupa silabus dan Rancangan Pelaksanaan Pembelajaran (RPP); (2) bahan ajar mengenai tokoh-tokoh pahlawan.

\section{Desain Produk}

Kegiatan yang dilakukan pada tahap ini adalah merancang desain media berbasis augmented reality bermuatan wawasan kebangsaan. Desain awal produk dimulai dari pengeditan gambar tokoh pahlawan, pembuatan audio mengenai deskripsi pahlawan, dan pembuatan video .mengenai cerita singkat dan deskripsi pahlawan.

Ada dua puluh tiga tokoh pahlawan yang terdiri atas pahlawan pada masa kerajaan hindu, pahlawan pada masa kerajaan budha, pahlawan pada masa kerajaan islam, pahlawan yang memperjuangkan kemerdekaan, dan pahlawan yang mempertahankan kemerdekaan. Proses editing gambar tokoh pahlawan menggunakan software Adobe Photoshop CS3. Pada pembuatan aplikasi ini, dibutuhkan gambar muka para tokoh pahlawan. Berikut ini adalah salah satu contoh gambar pahlawan yang sudah melalui tahap editing.

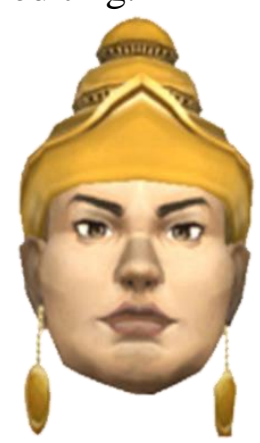

Gambar 1. Balaputradewa

Selanjutnya adalah melakukan pembuatan audio dan video deskripsi pahlawan. Proses pembuatan video dalam media ini menggunakan software microsoft 
power point. Hasil pembuatan video berupa file (*.mp4). Berikut ini adalah salah satu contoh video cerita singkat dan deskripsi pahlawan.

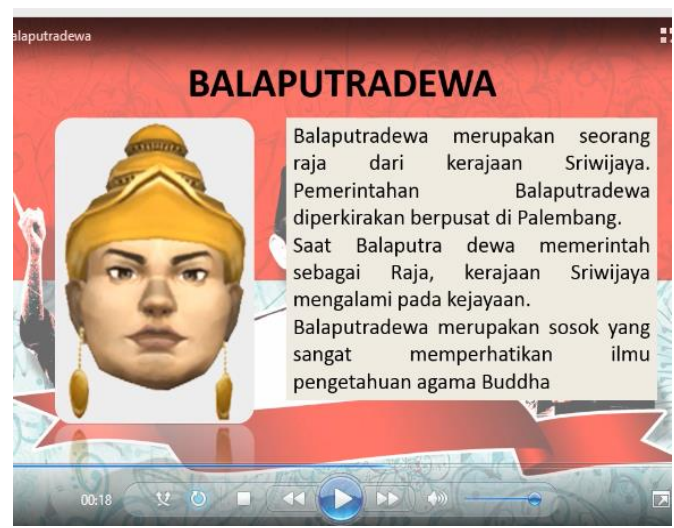

Gambar 2. Video Deskripsi

Setelah pembuatan video, langkah selanjutnya adalah pembuatan desain media. Berikut ini adalah tampilan awal media.

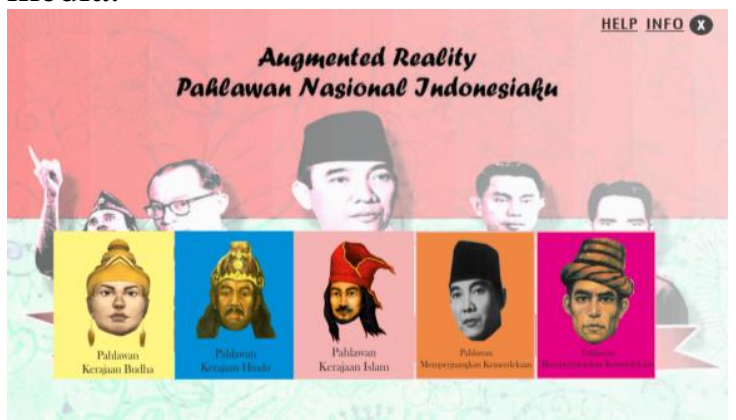

Gambar 3. Tampilan Awal Media

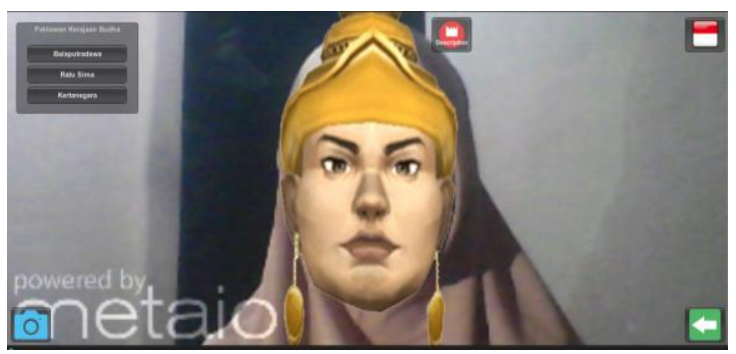

Gambar 4. Tampilan Gambar Pahlawan pada Wajah Pengguna

\section{Validasi Desain}

Desain media berbasis augmented reality yang telah dibuat selanjutnya produk divalidasi oleh 3 orang ahli yang terdiri dari 2 orang ahli media dan 1 orang ahli materi. 2 orang ahli media yaitu Nuur Wachid Abdul Majid, M.Pd seorang ahli IT dan dosen UPI Purwakarta dan Tyas Pratama Puja Kusuma, S.Kom., M.Pd seorang ahli
IT dan dosen Amikom Purwakarta. Sedangkan 1 orang ahli materi yaitu Desy Wulandari, S.Pd., SD selaku guru kelas VA SDN Kaggraksan. Berikut ini adalah hasil analisis uji validasi ahli media dengan 2 orang ahli media.

Tabel 2. Hasil Validasi Ahli Media

\begin{tabular}{|c|c|c|c|c|}
\hline \multirow[b]{2}{*}{ No } & \multirow[b]{2}{*}{ Indikator } & \multirow[b]{2}{*}{ Sub Indikator } & \multicolumn{2}{|c|}{ Validator } \\
\hline & & & V1 & V2 \\
\hline \multirow[t]{2}{*}{1.} & \multirow{2}{*}{$\begin{array}{l}\text { Rekayasa } \\
\text { perangkat } \\
\text { lunak }\end{array}$} & $\begin{array}{l}\text { Aplikasi berjalan } \\
\text { dengan lancar }\end{array}$ & 1 & 1 \\
\hline & & 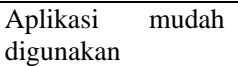 & 1 & 1 \\
\hline \multirow[t]{2}{*}{2.} & \multirow[b]{2}{*}{ Navigasi } & $\begin{array}{l}\text { Navigasi mudah } \\
\text { dipahami. }\end{array}$ & 1 & 1 \\
\hline & & $\begin{array}{l}\text { Tombol navigasi } \\
\text { berfungsi dengan } \\
\text { baik. }\end{array}$ & 1 & 1 \\
\hline 3. & Gambar & $\begin{array}{l}\text { Gambar yang } \\
\text { digunakan } \\
\text { menarik. }\end{array}$ & 1 & 0 \\
\hline 4. & Video & $\begin{array}{l}\text { Video yang } \\
\text { digunakan menarik }\end{array}$ & 1 & 1 \\
\hline \multirow[t]{2}{*}{5.} & \multirow[t]{2}{*}{$\begin{array}{l}\text { Musik atau } \\
\text { efek suara }\end{array}$} & $\begin{array}{l}\text { Suara yang } \\
\text { digunakan sesuai } \\
\text { dengan arakteristik } \\
\text { siswa Sekolah } \\
\text { Dasar } \\
\end{array}$ & 1 & 1 \\
\hline & & $\begin{array}{l}\text { Suara yang } \\
\text { digunakan tidak } \\
\text { mengganggu }\end{array}$ & 1 & 1 \\
\hline 6 & Penyajian & $\begin{array}{l}\text { Penyajian aplikasi } \\
\text { menarik dan sesuai } \\
\text { dengan } \\
\text { karakteristik siswa } \\
\text { Sekolah Dasar. }\end{array}$ & 1 & 1 \\
\hline \multicolumn{3}{|c|}{ Jumlah } & 9 & 8 \\
\hline \multicolumn{3}{|c|}{ Total } & \multicolumn{2}{|c|}{17} \\
\hline \multicolumn{3}{|c|}{ Rata-rata } & \multicolumn{2}{|c|}{8.5} \\
\hline \multicolumn{3}{|c|}{ Kategori } & \multicolumn{2}{|c|}{ Sangat Layak } \\
\hline \multicolumn{5}{|c|}{$\begin{array}{l}\text { Analisis data pengu } \\
\text { dihitung dengan rumus: } \\
\begin{aligned} \text { Presentase kelayakan }(\%) & =\frac{\text { skor yang dio }}{\text { skoryang diho }} \\
& =\frac{17}{18} \times 100 \% \\
& =94.4 \%\end{aligned}\end{array}$} \\
\hline
\end{tabular}

Dari hasil validasi media berbasis teknologi augmented reality bermuatan wawasan kebangsaan pada materi tokoh kepahlawanan, diperoleh bahwa media dalam kategori sangat layak dan didapat saran berupa perbaikan gambar pahlawan yang digunakan. Setelah melakukan ahli media, langkah selanjutnya adalah melakukan uji materi kepada ahli materi agar materi yang disajikan dalam media sesuai dengan materi yang diajarkan. Dari hasil uji materi didapatkan bahwa materi yang disajikan dalam media sudah valid 
dan sesuai dengan materi yang diajarkan di kelas V. Berikut ini adalah hasil analisis uji materi.

Tabel 3. Hasil Validasi Ahli Materi

\begin{tabular}{|c|c|c|c|c|}
\hline \multirow[b]{2}{*}{ No. } & \multirow{2}{*}{$\begin{array}{c}\text { Tokoh } \\
\text { Pahlawan }\end{array}$} & \multirow{2}{*}{$\begin{array}{c}\text { Nama } \\
\text { Pahlawan }\end{array}$} & \multicolumn{2}{|c|}{ Penilaian } \\
\hline & & & Valid & $\begin{array}{l}\text { Tidak } \\
\text { Valid }\end{array}$ \\
\hline \multirow[t]{6}{*}{1.} & \multirow{6}{*}{$\begin{array}{l}\text { Tokoh Pahlawan } \\
\text { Kerajaan Hindu }\end{array}$} & Purnawarman & Valid & - \\
\hline & & Ken Arok & Valid & - \\
\hline & & Jayabaya & Valid & - \\
\hline & & Raden Wijaya & Valid & - \\
\hline & & Gadjah Mada & Valid & - \\
\hline & & Hayam Wuruk & Valid & - \\
\hline \multirow[t]{3}{*}{2.} & \multirow{3}{*}{$\begin{array}{l}\text { Tokoh Pahlawan } \\
\text { Kerajaan Budha }\end{array}$} & Balaputradewa & Valid & - \\
\hline & & Ratu Sima & Valid & - \\
\hline & & Kertanegara & Valid & - \\
\hline \multirow[t]{4}{*}{3.} & \multirow[t]{4}{*}{$\begin{array}{l}\text { Tokoh Pahlawan } \\
\text { Kerajaan Islam }\end{array}$} & $\begin{array}{l}\text { Sultan } \\
\text { Hasanuddin }\end{array}$ & Valid & - \\
\hline & & $\begin{array}{l}\text { Sultan } \\
\text { Iskandar } \\
\text { Muda }\end{array}$ & Valid & - \\
\hline & & Rden Patah & Valid & - \\
\hline & & $\begin{array}{l}\text { Sultan Ageng } \\
\text { Tirtayasa }\end{array}$ & Valid & - \\
\hline \multirow[t]{6}{*}{4.} & \multirow{6}{*}{$\begin{array}{l}\text { Tokoh Pahlawan } \\
\text { yang } \\
\text { Memperjuangkan } \\
\text { Kemerdekaan }\end{array}$} & $\begin{array}{l}\text { Cut Nyak } \\
\text { Dien }\end{array}$ & Valid & - \\
\hline & & Pattimura & Valid & - \\
\hline & & Teuku Umar & Valid & - \\
\hline & & $\begin{array}{l}\text { Tuanku Imam } \\
\text { Bonjol }\end{array}$ & Valid & - \\
\hline & & R.A Kartini & Valid & - \\
\hline & & $\begin{array}{l}\text { Pangeran } \\
\text { Diponegoro }\end{array}$ & Valid & - \\
\hline \multirow[t]{4}{*}{5.} & \multirow{4}{*}{$\begin{array}{l}\text { Tokoh Pahlawan } \\
\text { yang } \\
\text { Mempertahankan } \\
\text { Kemerdekaan }\end{array}$} & Moh. Hatta & Valid & - \\
\hline & & Soekarno & Valid & - \\
\hline & & $\begin{array}{l}\text { Muhammad } \\
\text { Toha }\end{array}$ & Valid & - \\
\hline & & $\begin{array}{l}\text { Ki Hadjar } \\
\text { Dewantara }\end{array}$ & Valid & - \\
\hline
\end{tabular}

\section{Revisi Produk}

Revisi dilakukan berdasarkan penilaian, catatan, dan saran dari pakar yang telah memvalidasi. Berdasarkan hasil validasi ahli media didapatkan bahwa media perlu dilakukan perbaikan dalam hal menampilkan gambar pahlawan. Sedangkan hasil validasi ahli materi didapatkan bahwa materi sudah sesuai dengan materi pelajaran IPS mengenai tokoh kepahlawanan sehingga valid untuk digunakan dalam penelitian ini.

\section{Uji Coba Pemakaian}

Uji coba pemakaian dilakukan untuk mengetahui respon siswa dan guru terhadap media. Respon siswa dan guru dilihat dari ketertarikan terhadap media, kemudahan penggunaan media, penggunaan materi, bahasa, gambar, dan audio, dan keaktifan siswa pada saat menggunakan media.

Hasil respon siswa diperoleh dari angket respon siswa yang terdiri atas 15 pernyataan dan 4 pilihan jawaban yakni Sangat Setuju (SS), Setuju (S), Tidak Setuju (TS), dan Sangat Tidak Setuju (STS). Hasil respon siswa terhadap media adalah sebanyak $83.3 \%$ siswa menjawab Sangat Setuju dan sisanya $16.7 \%$ menjawab Setuju.

Sedangkan respon guru diperoleh dari angket respon guru yang terdiri atas 15 pernyataan dan 4 pilihan jawaban yakni Sangat Setuju (SS), Setuju (S), Tidak Setuju (TS), dan Sangat Tidak Setuju (STS). Responden adalah guru kelas V SDN Kanggaraksan. Hasil respon guru terhadap media adalah $73.3 \%$ dan masuk dalam kategori Baik.

\section{Pembahasan}

Perancangan Media Berbasis Teknologi Augmented Reality Bermuatan Wawasan Kebangsaan Pada Tokoh Kepahlawanan

Media berbasis teknologi Augmented Reality bermuatan wawasan kebangsaan dibuat dengan menggunakan software unity 3D dan metaio SDK. Aplikasi ini memungkinkan pengguna untuk membuat suatu aplikasi 2D/3D dan dapat memuat konten audio dan video.

Perancangan media pembelajaran ini dibuat sedemikian rupa agar menarik perhatian siswa ketika mengikuti pembelajaran IPS khususnya materi tokoh kepahlawanan. Dalam kegiatan pembelajaran, guru harus menyiapkan laptop yang dilengkapi dengan webcam. Guru menunjuk siswa untuk ke depan dan menghadapkan wajah ke depan webcam. Setelah itu, wajah siswa akan berubah seolah-olah menjadi wajah tokoh pahlawan.

Ada beberapa tampilan yang dibuat dalam media ini diantaranya adalah 
halaman depan media yang terdiri atas lima pilihan kategori materi tokoh kepahlawanan yakni pahlawan pada masa kerajaan hindu, pahlawan pada masa kerajaan budha, pahlawan pada masa kerajaan islam, pahlawan yang memperjuangkan kemerdekaan, dan pahlawan yang mempertahankan kemerdekaan. Kedua adalah halaman menu video deskripsi tokoh pahlawan dilengkapi juga dengan audio dubbing deskripsi pahlawan. Ketiga adalah halaman menu AR Camera yang berfungsi menampilkan wajah siswa seolah-olah menjadi wajah tokoh pahlawan

Ada dua puluh tiga pahlawan yang akan ditampilkan dalam media ini yang terdiri atas lima kategori yaitu tokoh pahlawan kerajaan hindu, tokoh pahlawan kejarajaan budha, tokoh pahlawan kerajaan islam, tokoh pahlawan yang memperjuangkan kemerdekaan, dan tokoh pahlawan yang mempertahankan kemerdekaan. Tokoh pahlawan kerajaan hindu yaitu Purnawarman, Ken Arok, Jayabaya, Raden Wijaya, Gadjah Mada, Hayam Wuruk. Tokoh pahlawan kerajaan budha yaitu Balaputradewa, Ratu Sima, Kertanegara. Tokoh pahlawan kerajaan islam yaitu Sultan Hasanuddin, Sultan Iskandar Muda, Raden Patah, Sultan Ageng Tirtayasa. Tokoh pahlawan yang memperjuangkan kemerdekaan yaitu Cut Nyak Dien, Pattimura, Teuku Umar, Tuanku Imam Bonjol, R.A Kartini, dan Pangeran Diponegoro. Tokoh Pahlawan yang mempertahankan kemerdekaan yaitu Moh. Hatta, Soekarno, Muhammad Toha, dan Ki Hadjar Dewantara.

\section{Kevalidan Media Berbasis Teknologi Augmented Reality Bermuatan Wawasan Kebangsaan Pada Tokoh Kepahlawanan}

Media divalidasi oleh 3 orang ahli yang terdiri dari 2 orang ahli media dan 1 orang ahli materi. 2 orang ahli media yaitu Nuur Wachid Abdul Majid, M.Pd seorang ahli IT dan dosen UPI Purwakarta dan Tyas Pratama Puja Kusuma, S.Kom., M.Pd seorang ahli IT dan dosen Amikom Purwakarta. Sedangkan 1 orang ahli materi yaitu Desy Wulandari, S.Pd., SD selaku guru kelas VA SDN Kaggraksan.

Dari 9 pernyataan yang diajukan, validator 1 menjawab $100 \%$ YA. Sedangkan validator 2 menjawab $89.9 \%$ YA dan 1 pernyataan dijawab TIDAK. Pernyataan yang dijawab tidak adalah pada bagian gambar. Menurutnya gambar pahlawan perlu direvisi dan disesuaikan ukurannya dengan wajah siswa.

Hasil validasi media menunjukkan bahwa skor media adalah $94.4 \%$ yang berarti media dalam kategori sangat layak dan dapat digunakan. Sementara hasil validasi materi diperoleh bahwa materi termasuk valid dan sesuai dengan materi tokoh kepahlawanan di kelas V SD.

\section{Respon Siswa dan Guru Terhadap Media Berbasis Teknologi Augmented Reality Bermuatan Wawasan Kebangsaan Pada Tokoh Kepahlawanan}

Respon siswa dan guru bertujuan untuk mengetahui seberapa besar respon siswa dan guru terhadap penggunaan media. Indikator yang digunakan adalah berdasarkan kemudahan penggunaan media, penggunaan materi, bahasa, gambar, dan audio, dan keaktifan siswa pada saat menggunakan media.

Angket dibuat dengan 15 pernyataan dengan 4 pilihan jawaban yakni Sangat Setuju (SS), Setuju (S), Tidak Setuju (TS), dan Sangat Tidak Setuju (STS). Respon siswa dan guru dilakukan pada saat tahap uji coba pemakaian produk. Uji coba ini dilakukan terhadap 30 siswa kelas V SDN Kanggraksan. Berdasarkan angket uji coba pemakaian media diperoleh hasil bahwa sebanyak $83.3 \%$ siswa menjawab Sangat Setuju dan sisanya $16.7 \%$ menjawab Setuju. Sedangkan hasil respon guru terhadap media adalah $73.3 \%$ dan masuk dalam kategori Baik.

Hasil penelitian ini didukung dengan penelitian yang telah dilakukan oleh Safaat, Nazruddin (2014), hasil penelitian menunjukkan bahwa dari hasil 
kuesioner yang diberikan kepada siswa dan guru diperoleh nilai $84.85 \%$ menyatakan bahwa Aplikasi AR-Book Tata Surya sangat membantu dalam memahami tata surya dan memberikan suatu kajian yang lebih menarik serta dapat mengatasi kekurangan alat peraga.

\section{KESIMPULAN}

Berdasarkan hasil penelitian dan pembahasan dapat sitarik kesimpulan sebagai berikut.

1. Perancangan media berbasis teknologi augmented reality bermuatan wawasan kebangsaan dikembangkan melalui tahapan potensi dan masalah, pengumpulan data, desain produk, validasi desain, revisi desain, dan uji coba pemakaian.

2. Validasi media diperoleh $94.4 \%$ media dalam kategori Sangat Layak.

3. Validasi ahli materi diperoleh hasil bahwa materi tergolong valid.

4. Hasil respon siswa terhadap media adalah sebanyak $83.3 \%$ siswa menjawab Sangat Setuju dan sisanya $16.7 \%$ menjawab Setuju.

5. Hasil respon guru terhadap media adalah $73.3 \%$ dan masuk dalam kategori Baik.

\section{DAFTAR PUSTAKA}

Ammatia, Risty. (2012). Augmented reality Paper, Diakses tanggal 3 Juni 2017 dari https://bit.ly/2IwPE9R

Ananda, T. A., Safriadi, N., \& Sukanto, S. A. (2015). Penerapan Augmented Reality sebagai Media Pembelajaran Mengenal Planet-planet di Tata Surya. Jurnal Sistem dan Teknologi Informasi, 1(1), 1-6

Efendi, A. (2008). Gagasan Nasionalisme dan Wawasan Kebangsaan dalam Novel Indonesia Modern. https://bit.ly/2KDc2em.(Online 9 Juni 2017).

Hadi, O. H. (2009). Nation and Character Building Melalui Pemahaman Wawasan Kebangsaan. Direktorat
Politik, Komunikasi, dan Informasi Bappenas.

Jazilah, Nur. (2016). Aplikasi Pembelajaran Berbasis Augmented reality pada Buku Panduan Wudhu untuk Anak. Malang: Universitas Islam Negeri Maulana Malik Ibrahim.

Martinez, Mario Z, Et Al. (2013). Mobile Serious Game Using Augmented reality for Supporting Childrens Learning about Animals. Spain: University of Valladolid.

Rahayuningsih, Fajar. (2009). Pendidikan Kewarganegaraan SD/MI Kelas IV. Jakarta: Pusat Perbukuan Departemen Pendidikan.

Rochmah, E., \& Labudasari, E. (2018). Prosiding Seminar Nasional Universitas Muhammadiyah Purwokerto. Penggunaan Media Berbasis Teknologi Augmented Reality Bermuatan Wawasan Kebangsaan pada Siswa Sekolah Dasar (pp. 80-87). Purwokerto: UMP Press.

Safaat, Nazruddin. (2014). Rancang Bangun Aplikasi Pembelajaran Berbasis Teknologi Augmented Reality Pada Smartphone Android (Studi Kasus : Materi Sistem Tata Surya Kelas Ix). Jurnal Mahasiswa Fakultas Sains dan Teknologi, 12(1).

Sudaryono, Guritno, \& Rahardja, A. (2011). Theory and Application of IT Research (Metodologi Penelitian Teknologi Informasi). Yogyakarta: Andi.

Sugiyono. (2010). Metode Penelitian Pendidikan (Pendekatan

Kuantitatif, Kualitatif dan $R \& D$ ). Bandung: Alfabeta.

Yasin., Trinugi., Elvin., (2016). Penerapan Teknologi AR (Augmented reality) pada Pembelajaran Energi Angin Kelas IV SD di Rumah Pintar AlBarokah. Jurnal Sistem Informasi. 